\title{
Open data and distributed knowledge work in open government
}

\author{
Margit Scholl* \\ FB WIR, UAS/TH Wildau, \\ Hochschulring 1, D-15745 Wildau, Germany \\ Email: margit.scholl@th-wildau.de \\ ${ }^{*}$ Corresponding author
}

\section{Maika Büschenfeldt}

Hamburg UAS, Berliner Tor 5,

D-20099 Hamburg, Germany

Email: maika.bueschenfeldt@haw-hamburg.de

\begin{abstract}
This concept paper looks at the potential of open standards and web services as a basis for innovation. It illustrates the capabilities and characteristics of open data in a conceptual way, comparing hierarchies and heterarchies as coordination models. Moreover, it will seek to show that the Web 2.0 technologies basically follow the same principles and coordination structures as the social models of collaborative knowledge generation and innovation, using open data as a foundation. The point is to make clear to what extent and in what form open data, open standards, and distributed applications are effective as a starting point for 'distributed knowledge work'.
\end{abstract}

Keywords: open data and standards; open government and e-government 2.0; Web 2.0; web services; collaboration knowledge; DKW; distributed knowledge work; innovation; coordination models; hierarchy; heterarchy.

Reference to this paper should be made as follows: Scholl, M. and Büschenfeldt, M. (2014) 'Open data and distributed knowledge work in open government', Int. J. Innovation in Education, Vol. 2, Nos. 2/3/4, pp.137-150.

Biographical notes: Margit Scholl after studying Physics/Meteorology in Mainz and Berlin, she worked as a researcher on a number of projects for the German Research Foundation (DFG), developing numerical models. She did her doctorate in Meteorology at Berlin's Freie Universität. Afterwards she was a unit head within the Berlin Senate administration. In 1994, she was granted a professorship at the University of Applied Administrative Sciences Bernau. From 1998 to 2001, she was head of the IT user service in the Brandenburg State Office for Data Processing and Statistics. In 2001, she returned to the UASWi as a Professor of Business and Administrative Computing.

Maika Büschenfeldt is Deputy Professor in the Department of Information at the University of Applied Science in Hamburg. She studied Sociology and Computer Science in Hamburg and completed her $\mathrm{PhD}$ thesis at the University of Bremen. Her professional and scientific focus is on software development (especially web development) databases and project management in context of e-democracy, e-government, e-learning and business. 


\section{Introduction}

The term open government is generally used to indicate all measures taken by governments and modern administrations to open up their decision-making processes and knowledge, making them accessible to both the civil and commercial worlds. The starting point was the memorandum issued by the US president (Obama, 2009) in which he promised that his "administration is committed to creating an unprecedented level of openness in government" and "will work together to ensure the public trust and establish a system of transparency, public participation, and collaboration". Subsequently, city services were compared, which showed, for example, that the City of Seattle had repeatedly been acclaimed for its interactive web portal and open data sites and had won several national awards among US municipalities with a population of over 100,000 (Bishop, 2011). However, research has highlighted the contradiction between open data's transparency goal ("All data must be free") and federal agencies' goal of collaborating with each other through data trade (Peled, 2011).

Moreover, research on open government can also be seen in the context of smart-city initiatives along the lines of the Smart City Framework (Chourabi et al., 2012). Actionable information and communication technologies have been said to be the key prerequisite and backbone for developing models of smart (democratic) governance, which foster smart, open and agile governmental institutions, as well as constituent participation and collaboration on all levels and in all branches of the governing process (Scholl and Scholl, 2014). However, thus far, the two concepts of smart government and smart governance are still not very far advanced. Smart government has to cope with complexity and uncertainty and needs to build up competencies and achieve resilience (Willke, 2007). Smart-governance infrastructure is seen as an agglomerate of elements such as norms, policies, practices, information, technologies, skills and other resources (Johnston and Hansen, 2011). Several key factors have been identified, such as problem focus, feasibility/implementability, the constituents' ability to contribute, continued involvement in the process, coordination, and access to open data and shared information (Johnston and Hansen, 2011). Moreover, interoperability is a key factor, too (Scholl et al., 2012). Judging from traditional electronic government (e-government) research, smart governance and the administrative enactment of smart and open government will encompass broader fields of interest in the larger context of the society and environment of the 21st century: smart administration, smart interaction with stakeholders, smart security and safety, and smart infrastructures, based on information and communication technology (Scholl and Scholl, 2014).

It was hoped that open government, both in Europe and worldwide, would not only engender more transparency through democratic participation and decision-making processes that would include all levels, but also create the basis for innovations through across-the-board cooperation. The open-government approach can be understood as a customisation of government and administrative activities in line with the demands of the knowledge society; admittedly this has not yet been achieved but it is in the pipeline. The sociological term knowledge society ${ }^{1}$ describes the economic dimension of the societal shift from an industrial to a post-industrial society. For more than a decade the substantial increase in the importance of knowledge as the key resource and a production factor in society and science - and as an established fact in business and administration - has been discussed as a main feature of the knowledge society. The idea 
is that knowledge will outstrip the classical productive forces - land, labour and capital in terms of economic importance (Willke, 2001).

In this concept paper, the handling and processing of knowledge is seen as a precondition for democratic participation and cross-functional cooperation. Knowledge is approached here from two angles: firstly as a pecuniary resource and secondly as a political factor, which "can lead to new power structures' within a society through the loss of data rights" (McKinnon, 2010). In the current discussions about open government, the handling of knowledge is dealt with under the rubrics open data and open government data. Open data are defined as all data records that are made accessible for the general public interest "without any restriction on free usage, further distribution and free reutilisation" (von Lucke and Geiger, 2010, p.3). The term open government data are used when free data refers specifically to data records in the public sector. The generic name open data covers not only government and public administration data records but also includes input from the private sector, from educational institutions, from non-profit organisations, and from broadcasting corporations. In distinction to open access data records, open data does not only limit itself to text form but also includes all data formats, e.g., geodata and maps, statistics, weather data, traffic data and transport schedules. Moreover, the demand for open data does not only involve free access to data but also the collaborative generation of new data. When data are put in a meaningful context for the people who are handling it, it will thereafter be termed 'knowledge' (see Büschenfeldt and Scholl, 2013). With open data it is not simply a question of processing data on the technical level but of having free access to knowledge and collaboratively producing new knowledge on the social level.

Open government, open data and open government data are mostly bracketed together with the technical potentials offered by cooperating in knowledge production and distributing knowledge. Interoperability and Web 2.0 technologies should contribute to the further development of government and administrative activities as they move towards Transparency 2.0, Participation 2.0 and Collaboration 2.0 (see von Lucke, 2012). In this sense, open government is becoming a primary goal of IT strategy (cf. Klessmann et al., 2012). Chapters 2 and 3 will illustrate the capabilities and characteristics of open data, comparing hierarchies and heterarchies as coordination models, while Chapter 4 focuses on the term distributed knowledge work (DKW). At the end some future perspectives will be offered.

\section{Hierarchies and heterarchies as models of action coordination}

In a classical organisation, action coordination is traditionally carried out hierarchically and characterised by clear delimitations and formal structures. The management theorist Helmut Willke labels this coordination principle as a hierarchy, which he describes as "a model of non-coequal, heteronomous and centralised coordination". He contrasts hierarchies with the counter-concept of "coequal, self-organised and decentralised coordination" (Willke, 1998, pp.89-90). In organisational theory this form of action coordination is termed heterarchy - Willke speaks of a 'democratic coordination model'. In reality these two coordination models are not found in their pure form and serve as idealised types representing a target-oriented and constructed idea that highlights the key aspects of (social) reality by means of conscious exaggeration (cf. Weber, 1968, p.190ff; 
Reihlen, 1996, 1998, p.42). Summarising the two textbook-case model types (see Büschenfeldt and Scholl, 2014), we can view:

- The hierarchy as a model of regulation with strong management requirements.

The key features are clear demarcations, centralisation, non-coequality, heteronomy, and a high degree of process linkage. The hierarchical model is oriented towards stability and planning reliability.

- The heterarchy as an unobtrusive model with a low-level management requirement. Its characteristics are openness, decentralisation, coequality, self-management, and a lower level of process linkage (loose coupling). The heterarchical management model is oriented towards flexibility and the ability to innovate.

As shown in Büschenfeldt and Scholl (2014) and applied to Web 2.0 archetypes, demarcation defines the delimitation mechanisms of a coordination model. This means that demarcation can be used to define whether a system is to be characterised as open or closed. The organisational structure signifies the type of relationships existing between the elements of a system and the degree to which processes are interlinked. The degree of linkage gives an indication of how strictly the sequence of activities (processes) is regimented through defaults and predefinitions, and how great or small are the margins of variance. The aspect of structural change refers to the ability of a system to foster stability or allow flexibility.

Clear demarcations, non-coequal structural make-up, and a high degree of process linkage are evidence of the dominance of hierarchical coordination and management structures. Heterarchical structures can be found, in turn, in the blurring of boundaries and openness, in the co-equal structural make-up of the network, and a lower degree of process linkage. The type of coordination model and the context in which it is used - to tackle what kind of problem and in what kind of environment - can thus be determined by means of indicators using the system dimensions mentioned above: demarcation, structure and structural change. These indicators can be derived from the characteristics of the coordination models that have already been delineated. As described in Scholl and Büschenfeldt (2012), three types of indicator can be used: Boundary indicators refer to the demarcations of a system; they regulate what is included and excluded. Structural indicators refer to structural build and processes. Revision indicators refer to the flexibility or stability of a system. Evaluating the suitability of formalism and planning is then dependent on the degree of problem complexity. On the basis of Helmut Willke's theory of intervention, we can broadly differentiate between three problem types: so-called white box, grey box, and black box problems (Willke, 1996, p.211ff.), which have already been presented in detail in another context (Scholl and Büschenfeldt, 2011).

While media attention is currently focused on Public Administration $4.0{ }^{2}$ the real question is whether we actually know what e-government 2.0 is. In Büschenfeldt and Scholl (2014), we propose specifying the concepts of Web 2.0 and e-government 2.0 based on the two models of coordination, heterarchy and hierarchy, as well as the system dimensions. The archetypes wikis, blogs, and microblogging are also examined. In this analysis, we define the concept of e-government 2.0 as an extension of the e-government definition put forward by von Lucke and Reinermann (2000) - as a system of electronically based governmental and administrative processes set up according to the principles of Web 2.0 coordination. We understand e-government 2.0 as an approach to using the coordination principles of Web 2.0 as a reference model for administrative 
modernisation. The decisive factor will be social innovation (Büschenfeldt and Scholl, 2014). In the next chapter, we examine the three system dimensions with respect to open data.

\section{Open data and collaboration}

Open data and open government are concerned, on the one hand, with free and unrestricted access to data and, on the other, with a special form of collaborative knowledge production and the transparency of administrative and governmental activity on the basis of free data. In our presentation we make distinction between the technical and social levels, which we would like to describe in terms of the following system parameters: demarcation, structure, and structural change. On the technical level the feature of free access to data has its equivalent in the requirement for interoperability through open standards. This is the only way for data to be exchanged and made available via Web 2.0 applications and technologies (see Scholl et al., 2012). Here the visions embodied in Transparency 2.0, Participation 2.0 and Collaboration 2.0 are realised on the back of open data and mediated by Web 2.0 technologies and applications (see von Lucke and Geiger, 2010).

\subsection{Demarcation}

Openness is not simply an aspect of the term 'open data' - it is the main characteristic of it. Following the coordination model described above, the openness of open data in the first instance refers to the feature of demarcation. In the discourse on democratic theory, this question touches on the inclusion or exclusion of interested parties and the opinions, issues and people involved (Habermas, 1994). ${ }^{3}$ Boundaries also determine access to intellectual commodities such as knowledge, standards or source code. The degree of openness of this access influences the way in which new information, new knowledge, or new products can be produced. For this reason, the Open Source movement and the specific development practices of Web 2.0 rely explicitly on waiving exclusive rights to access and utilisation as the basis for distributed development and for programmer and innovation models. In the struggle for access to intellectual resources, the principal issues revolve around transparency and the power to control.

Open data means designing access to data and new data production in a way that is consciously open. This openness can only be achieved if the conditions have been created on the technical level for data to be exchanged in heterogeneous software and hardware worlds. For this reason, interoperability is also one of the key issues in open government and is nowadays a 'must' for modern IT infrastructures. Interoperability can only be achieved through standardisation. What is interesting is that standards can themselves be understood as knowledge and may, like all other forms of knowledge, be freely available in the public domain or subject to copyright protection as intellectual property'. There is some indication that the extraordinary success and penetration of the internet are conditional on its standards being openly and freely available, not on their being protected. ${ }^{4}$ In particular, it is the open web standards - which serve as the World Wide Web Consortium (W3C) specifications for the implementation of every web technology and application - that are hailed as the basis for open data and open government. First and foremost, they allow the internet to be consistent and 
interoperable. Although there has, to date, been no universally valid definition of open standards, two commonalities can be identified amongst the plethora of suggestions:

- open standards must be developed openly and transparently and be inclusive of all parties concerned

- open standards must be freely accessible.

Open standards thus stand in and of themselves for transparency, openness, and the relinquishment of control, or for a control that is in the hands of all the actors involved and not surrendered to representatives of a superordinate level in the hierarchy. This means that they are also an example of the principle of participation. Mediated by the application options on the technical level, they are an important basis for the free distribution of knowledge and collaborative knowledge work in communities and beyond.

\subsection{Organisational structure}

On the level of structural build and processes, there is potential for sharing and interoperability in the networking of open data in the form of linked open data (LOD). This opens up the possibility of using data across domains and organisational boundaries and interlinking it. The sharing and interoperability of data and applications open up, as it were, new channels of knowledge distribution and generation that are created by spatially distributed applications and lightweight programming models. This also leads to further development of the internet. Part of this development is the web services concept, which in recent years has grown into an informatics paradigm. The idea behind it is simple and straightforward: complex applications are not run in a centralised way on one server. Instead they are made up of different components that can be distributed across the internet. Communication between the components takes place by means of clearly defined Application Programming Interfaces (API), which, on demand, can be integrated into an application (Schwenk, 2010, p.216). From this perspective, web services can be understood as networked machine-to-machine communication, which is as a rule automated; its common language is based on open, manufacturer-independent standards (Zeppenfeld and Finger, 2009, p.38). Collections of services in grid frameworks based on service-oriented architecture (SOA) models are used for the design of distributed knowledge discovery processes (Talia and Trunfio, 2010).

As a nexus of various applications, web services have two invariable requirements: a paradigm shift in the understanding of the role and function of software and in the handling of data, governance, and access rights. It is clear in this paradigm shift that the principle of openness is operative in the concept of web services. With this in mind, we might say that openness through the relinquishment of control is one of the key values of this paradigm shift: at the technical level, it provides the basis for the free exchange of data and functions (Büschenfeldt, 2011, p.135ff.). O'Reilly calls this crucial aspect of giving up control 'cooperation without coordination' (O'Reilly, 2005). The real value of these services lies not in the applications but in the data behind the applications. This data will be made available to other applications via open interfaces (APIs). The distribution and exchange of data take place by means of simple technologies, which make the data available but do not control its utilisation at the other end of the line (O'Reilly, 2005). 
The potential contained in distributed functionality and data has spawned the very applications and social networking options that have enabled people to join together as virtual communities and fuel the visions contained in Transparency 2.0, Participation 2.0 and Collaboration 2.0. Openness stands here, on both the technical and the social level, for a coordination model of open, coequal, and decentralised networking without the need for control. If we are dealing here with open and networked data originating in the public sector, then we may extend the term open government data to include the special feature of networking. On the basis of von Lucke and Geiger's operational definition, one characteristic of open government data is that it is made available in a way that allows it to be freely networked. This includes making public sector data "openly and unrestrictedly available for free use, redistribution and free reutilisation in the interests of the general public" (von Lucke and Geiger, 2010, p.6).

\subsection{Structural change and innovation}

The aspect of structural change relates to the capacity of heterarchical structures to learn and innovate. These are characteristic features of Web 2.0/Social Media. Open data's valued added becomes clear when looked at in terms of heterarchical networking, where data records that were not previously linked to one another are combined in an innovative way, potentially opening the way to new insights (von Lucke and Geiger, 2010, p.3). The web pioneer Tim O'Reilly considers the relinquishing of control and the free availability of data and functionality as the prerequisite for one of Web 2.0's key features, innovation through the assembling of components. The loose coupling of distributed data and functionality thus opens up whole new prospects for software innovation, based on the possibility of accessing other services with relative freedom and combining them with one's own. O'Reilly describes this as 'the right to remix'. In this way, a whole array of different applications could flourish under the label 'mash-ups'. These get their value added primarily from imported content and are enriched in the process by the combination of numerous services, while still remaining simple (O'Reilly, 2005; Koch and Richter, 2009).

Open-data and peer-networking structures determine the working methods of knowledge communities and lead to the appearance of the kind of phenomena that have been vaunted under the banner of social media or Web 2.0. This includes, for instance, the democratisation of the media through user-generated content and the development of collective intelligence or crowdsourcing. This can be seen not only in friendship networks or in the exchange of trivia but also in serious and productive knowledge work. This is confirmed by more recent research work, such as the empirical studies carried out by MIT's Eric von Hippel. His work has identified a new type of innovator in, of all places, the supposedly passive user community, the social entities that make possible "the development, distribution and, to some extent too, the production of innovations by users, for users" - what von Hippel terms user innovation networks. They reduce the importance of manufacturers, who up to now have been thought of as the intermediaries for innovation, going so far as to make them expendable when it comes to information products (von Hippel, 2005). Here too the characteristic feature of these networks is their heterarchical structure, i.e., their horizontal and interconnected structure. The boundaries between the actor groups involved, such as producer and consumer, are blurred, along with the dividing line that separates the development and use of the evolved products. Everyone involved in these networks is an 'innovative user' or 'user/self-manufacturer' 
and capable not only of consuming innovations but also of developing, producing, and distributing them (von Hippel, 2005, p.453). An almost perfect example of this are open source communities, which were also the subject of von Hippel's studies.

\section{Distributed knowledge work}

The term DKW is inspired by Helmut Willke's organised knowledge work. 'Knowledge work' here is deemed to be an activity that requires knowledge and produces knowledge, and is characterised by the fact that it is considered to be permanently in need of revision and is viewed as a resource. Organised knowledge work uses the process of organisation to develop knowledge as a productive force (Willke, 2001). The term DKW, as we use it, refers to knowledge in the same sense but is removed from the context of a definable organisation and applied to the collaborative work of those communities that also dedicate themselves to knowledge work.

The potential for distributing functionality and data through web services produces the very applications and networking options that are needed to facilitate DKW in networked communities beyond the boundaries of clearly defined organisations. Interestingly, both the technical basis and the forms of cooperation rely at the (social) application level on a common principle, or 'democratic principle' (Büschenfeldt, 2011), a name inspired by Willke's theory of management - this principle is based on the idea of "self-organised, decentralised, peer-to-peer coordination" (Willke, 1998, pp. 89-90).

The increasing importance of knowledge as a resource also raises the question of how knowledge should be dealt with in the future and how the distribution, use, and production of knowledge can be managed. Here, in particular, what is at issue is the control of knowledge, i.e., the regulation of the access to knowledge and the decision as to whether knowledge is a commodity - which can then be viewed as the basis for intellectual property - or should be treated essentially as a public asset (Grassmuck, 2004). There are two opposing interests and positions at stake here:

- The first position focuses on safeguarding the ownership of know-ledge through copyrighting and investment protection: knowledge protection serves to secure innovations and preserve competitive advantage. According to this, the investments required for innovations can only be made if the knowledge that is acquired can be effectively protected. Knowledge can "lose significantly in value if it is wrongly distributed" (Clases and Wehner, 2002, p.51).

- The second position emphasises society's interest in the free availability of knowledge. The argument is that knowledge freedom guarantees innovation and research. Innovation always needs a certain degree of openness, too (see Grassmuck, 2004).

The legal and economic battle for the control of the production and distribution of knowledge has already been fought. Traditionally this battle has been carried on in the courts, i.e., by means of the commercial copyrighting of intellectual property. The technological advances that have enabled the decentralised distribution of knowledge and information via the internet also play a major role here, and this possibility has fuelled and accentuated the struggle (Drossou et al., 2006, p.1). We proceed from the assumption that the internet's communication infrastructure does not simply serve to intensify the 
debate surrounding the control of knowledge - rather it provides active governance in much the same way as the law does (see Lessig, 1999). Technical measures thus become an instrument of deliberate and targeted social intervention. It may be inferred from this that the code is also a proper and effective regulatory instrument for dealing with knowledge. This is also suggested by the fact that Lessig's line of argument focuses in particular on copyright measures, which, at the time his book appeared, were actually in breach of established law. The procedures that are currently being discussed as a means to control the use and distribution of digital content through Digital Rights Management (DRM) systems are a typical example of how to limit access to knowledge using technical measures - regulation, that is, not only by legal but, more particularly, by technical means.

If the exchange between networked web applications runs automatically, peer-to-peer and cross-linkage mechanisms come back into play in the open handling of data and programme functions. Both have some degree of influence on the way technical components are designed. One prerequisite is dealing openly with knowledge and data. This applies, as we mentioned earlier, to open technical standards, which provide for consistency and interoperability in the internet, to the provision of data and functionality through web services, and above all to the internet as a programming platform.

DKW can, in turn, be seen as a basis for managing the complexity of current challenges and creating value added, especially for governments and public administrations. There is good reason to explicitly link the strategic opening up of administrative organisation and its processes with the inclusion of actors from outside the administrative sphere and the knowledge they have. The most recent example in Germany is the public discussion of the Key Issues Paper produced by the IT Planning Committee $^{5}$ on Open Government via internet, annotation of which was possible up until 22 June 2012. Its results were reviewed and had some influence on the final formulation of a position on open government.

There are a number of different factors that will determine what data is published as open government data and under what conditions - licensed or unlicensed. They will also have a bearing on whether the data provided can be designated as open. Usage costs, legal terms, and criteria such as simple retrievability, electronic availability, machine interpretability and usable formats are in the process of being sorted out. The study commissioned by the Federal Ministry of the Interior (BMI), 'Open Government Data Germany', which was submitted in July 2012, investigated payment models for open government data, governance (i.e., structuring and coordination) for open government in Germany, and operating models for the open government platform, which has been a target since 2013. It also formulated 54 short-, medium- and long-term recommendations for federal, state and local government (Klessmann et al., 2012). Admittedly, by definition, data that has to be paid for is no longer classed as open data. However, in this discussion Germany is putting itself in line with worldwide government trends and with the European Commission, whose aim is to explain open government as a goal of their IT strategy, even if it remains unclear at the time of writing how far administrations can, will, or should go with open data. As explained in the BMI study, "the aspect of openness constitutes an approach to the structuring of processes and is an attempt to orientate strategic decisions" (Klessmann et al., 2012, p.7). 


\section{Prospects for the future}

The democratic principle is possible, because innovative web applications allow users the freedom they need to connect with each other and network their knowledge. This knowledge networking demonstrates the innovative potential of serious knowledge work and the possibility of creating value added.

Co-equality, openness and a dialogic communication structure are interesting options for open government but there are some limitations imposed on the debate by various legal considerations.
"Information freedom is an element of modern statehood and will, in future, be an increasingly essential component of a participative democratic constitutional state. In the new understanding of transparency, it no longer just means the possibility for citizens to draw information from generally accessible sources or to apply for it from administrative bodies. Instead, it involves the active disclosure of information and opinion-forming, consultation and decision-making processes; it also means making data from public authorities available to third parties both inside and outside of public bodies." (Klessmann et al., 2012, p.8)

In its long version, the BMI study shows in detail that open administrative data offers a range of opportunities for the various target groups, as well as involving a number of different challenges. The disclosure of data records and their use and reutilisation by so-called third parties could also bring with it positive effects such as quality assurance and quality improvement. Public administration can only profit from the knowledge of all the actors concerned, once it abandons its need for control and access restrictions. Moreover, the knowledge possessed by administrative staff members is also a resource that can be developed at a personal level and then deployed, or not, as the case may be. Here structural changes in context management may be helpful in achieving more powerful and more motivating self-organisation (see Scholl and Büschenfeldt, 2011). Thus, open government will also have to effect changes in knowledge work within public administrative structures in order to promote DKW with actors from outside the administrative world so that peer-to-peer participation and open transparency can result in a dialogic communication structure.

Yet, as von Lucke (2010) has stressed, open government is far more than just open government data. In the "Memorandum zur Öffnung von Staat und Verwaltung (Open Government)" put out by the Gesellschaft für Informatik (GI, 2012), seven premises were identified that are consistent with future open governmental and administrative activities in the 21 st century: openness, transparency, responsibility, participation, cooperation, coherence and (national) economic benefit. The broad acceptance and concrete shaping of these propositions represents one of the challenges faced at the moment. "Agreement on a common understanding with a clear set of objectives for successful implementation" is needed. Open Government involves a "fundamental shift of paradigm and perspective" and, when it comes to the active design process, the question is what particular focus will be put on openness in Germany. From the point of view of the GI's specialised committee Informatics in Public Administration and its Informatics and Public Law department, we are only at the opening stage of a long debate. Our paper's contention is that all seven premises should be scientifically investigated on the basis of the indicators identified for the coordination models. 
As we explained in the previous section, openness in the sense of removing barriers is becoming a fundamental aspect of self-regulated, peer-level coordination in the network. Not only can this type of coordination be found on the social level but it also determines the principles underlying Web 2.0 technologies. If the exchange between networked web applications is also automated, then we can again find, in the open approach to data and programme functions, precisely those peer-to-peer and cross-linkage mechanisms that have hitherto ensured the spirit of innovation in the internet. This holds true for the open technical standards that deliver consistency and interoperability in the net, for the provision of data and functionality via web services, and for the internet as a programming platform. The principle of network neutrality demonstrates with particular clarity how openness and the dissolution of boundaries are achieved in a democratic communication structure and how they give the internet its decentralised many-to-many structure. This principle is implemented in the end-to-end policy, which, above all, makes it clear what openness requires. There are three aspects here (Saltzer et al., 1984; Sandvig, 2003):

- $\quad$ openness for all users and usages

- a polycentric (many-to-many) network architecture in the transport system

- fair, discrimination-free access for all users and usages.

The internet's design principle demonstrates that open data in its ideal form requires all usage restrictions and controls to be removed. The real irony seems to lie in the connection between the manifold possibilities of networked exchange offered by new communication technologies and the reality of data that is predominately locked up and restricted in its usage rights. But knowledge is highly charged. The significant increase in the importance of knowledge as one of the key resources and a 'production factor' in society, science, commerce and administration provides an indication of the highly charged nature of open data.

Knowledge is set to overtake the classical factors of production such as land, labour and capital in terms of its economic importance (Willke, 2001). What stands out as a clear trend is that the market is visibly dominated by products whose value is based on built-in expertise, as is the case with high-tech products. As a result, knowledge is a component of many business models that are founded on artificial scarcity and access restrictions. This can be seen, in particular, in the intense debate about intellectual property, which is marked by political lobbyism and is being held - explicitly in the argument about the revised version of copyright and patent law - against the backdrop of the new technologies (Büschenfeldt, 2011, p.150). The provision of governmental and administrative data goes along with the need to respect the conflict of interests at stake. These include the public interest in transparency and freedom of information and, at the other end of the scale, data security and the protection of industrial and commercial secrets (von Lucke and Geiger, 2010, p.6). Web 2.0 enables open government as a political and social paradigm, giving new transparency to the state and creating innovative forms of citizen participation (see Dapp and Geiger, 2011). DKW can only develop its potential in a creative, open, and trustful environment. The most important question in the context of open data and open government still needs to be resolved - the way knowledge is to be handled in the future and where the boundary should be set between privacy, restriction and openness. 


\section{References}

Bishop, T. (2011) 'City of seattle's site named 'Best of the Web' for U.S. cities', GeekWire: Dispatches from the Digital Frontier, GeekWire, LLC, Seattle, WA, p.1, Retrieved from http://www.geekwire.com/2011/city-seattles-website-named-best-web-cities/ (Accessed on 11 November, 2014).

Büschenfeldt, M. (2011) Die Zukunft elektronischer Demokratie: Die Bedeutung des demokratischen Prinzips in Softwaretechnischen Konzepten und der Elektronischen Demokratie als Anwendungsdomäne der Softwareentwicklung, E-dissertation, Bremen.

Büschenfeldt, M. and Scholl, M. (2013) Offene Standards und verteilte Anwendungen als Grundlage 'verteilter Wissensarbeit' (auch) im Open Government, TH Wildau scientific papers.

Büschenfeldt, M. and Scholl, M. (2014) 'Die archetypen des Web 2.0 als referenzmodell für das E-government 2.0', in Dekan, F.B.A. and Verwaltung, HWR Berlin (Eds.): Beiträge zur Verwaltungsinformatik, Ergänzungsband zur GI- Fachtagung, Gemeinsam Electronic Government ziel(gruppen)-gerecht gestalten und organisieren', 20-21 March 2014, Berlin, No. 19/2014, pp.117-139.

Chourabi, H., Nam, T., Walker, S., Gil-Garcia, J.R., Mellouli, S., Nahon, K. and Scholl, H.J. (2012) 'Understanding smart cities: an integrative framework', 2012 45th Hawaii International Conference on System Sciences, IEEE, pp.2289-2297, doi:10.1109/HICSS.2012.615

Clases, C. and Wehner, T. (2002) 'Steps across the border: Cooperation, knowledge production and systems design', Computer-Supported Cooperative Work: The Journal of Collaborative Computing, Special Issue on Activity Theory and Design, Vol. 11, Nos. 1-2, pp.39-54.

Dapp, M.M. and Geiger, C.P. (2011) 'Munich open government day: bürgerschaftliches engagement im Web 2.0', HMD Praxis der Wirtschaftsinformatik, Vol. 48, No. 4, pp.26-36.

Drossou, O., Krempl, S. and Poltermann, A. (Eds.) (2006) Die wunderbare Wissensvermehrung: Wie Open Innovation Unsere Welt Revolutioniert, 1st ed., Heise, Hannover.

Gesellschaft für Informatik (GI, 2012) GI (Gesellschaft für Informatik e.V.) [German Informatics Society] Memorandum zur Öffnung von Staat und Verwaltung, http://fbrvi.gi.de/fileadmin/gliederungen/fg-vi/FGVI-121016-GI-PositionspapierOpenGovernment.pdf (Accessed on 17 October, 2012).

Grassmuck, V. (2004) Freie Software: Zwischen Privat- und Gemeineigentum, 2nd ed., Bundeszentrale für politische Bildung, Bonn.

Habermas, J. (1994) Faktizität und Geltung: Beiträge zur Diskurstheorie des Rechts und des demokratischen Rechtsstaats, 4th ed., Suhrkamp, Frankfurt am Main.

Johnston, E.W. and Hansen, D.L. (2011) 'Design lessons for smart governance infrastructures', American Governance, Vol. 3, pp.1-30.

Klessmann, J., Denker P., Schieferdecker I. and Schulz, S.E. (2012) Open Government Data Deutschland: Kurzfassung der Studie zu Open Government in Deutschland im Auftrag des Bundesministerium des Innern (BMI), Berlin, http://www.bmi.bund.de/SharedDocs/ Downloads/DE/Themen/OED_Verwaltung/ModerneVerwaltung/opengovernment.pdf?_blob $=$ publicationFile (Accessed on 11 November, 2014).

Koch, M. and Richter, A. (2009) Enterprise 2.0: Planung, Einführung und erfolgreicher Einsatz von Social Software in Unternehmen, 2nd ed., Oldenbourg Wissenschaftsverlag, Munich.

Lessig, L. (1999) Code and Other Laws of Cyberspace, Basic Books, New York.

Lucke, J.v. (Ed.) (2012) Entdeckung, Erkundung und Entwicklung 2.0: Open Government, Open Government Data und Open Budget 2.0, Vol. 1. epubli.

McKinnon, R. (2010) from a re:publica lecture. In: 'Open data: mit alten daten neues wissen schaffen', Zeit Online, 16 April, 2010, http://www.zeit.de/digital/internet/2010-04/open-datarepublica/seite-1 (Accessed on 12 October, 2010). 
O'Reilly, T. (2005) What Is Web 2.0? Design Patterns and Business Models for the Next Generation of Software, http://www.oreilly.com/pub/a/web2/archive/what-is-web-20.html (Accessed on 16 July, 2008).

Obama, B. (2009) Transparency and Open Government, Memorandum for the Heads of Executive Departments and Agencies.

Peled, A. (2011) 'When transparency and collaboration collide: the USA open data program', Journal of the American Society for Information Science and Technology, Vol. 62, No. 11, pp.2085-2094.

Reihlen, M. (1996) The Logic of Heterarchies: Making Organizations Competitive for Knowledgebased Competition, Cologne: University of Cologne., Seminar für Allgemeine Betriebswirtschaftslehre, Betriebswirtschaftliche Planung und Logistik. http://hdl.handle.net/ 10419/59784, Working Paper Series, p.8ff (Accessed on 11 November, 2014).

Reihlen, M. (1998) Die Heterarchie als Postbürokratisches Organisationsmodell der Zukunft? University of Cologne, Cologne, http://www.econbiz.de/archiv/k/uk/splanung/heterarchie organisationsmodell.pdf

Saltzer, J.H., Reed, D.P. and Clark, D.D. (1984) 'End-to-end arguments in system designs', $A C M$ Transactions on Computer Systems, Vol. 2, No. 4, pp.277-288, http://web.mit.edu/Saltzer/ www/publications/endtoend/endtoend.pdf (Accessed on 8 August, 2009).

Sandvig, C. (2003) 'Shaping science and technology policy: the next generation of research', in Guston, D. and Sarewitz, D. (Eds.): University of Wisconsin Press, Draft version, Madison, http://faculty.las.illinois.edu/csandvig/research/Communication_Infrastructure_and_Innovatio n.pdf (Accessed on 25 September, 2006).

Scholl, H.J. and Scholl, M.C. (2014) 'Smart governance: a roadmap for research and practice', in Kindling, M. and Greifeneder, E. (Eds.): Proceedings of the 9th iConference, Berlin, Germany. Illinois Digital Environment for Access to Learning and Scholarship (IDEALS), pp.163-176.

Scholl, H.J., Kubicek, H., Cimander, R. and Klischewski, R. (2012) 'Process integration, information sharing, and system interoperation in government: a comparative case analysis', Government Information Quarterly, Vol. 29, pp.313-323.

Scholl, M. and Büschenfeldt, M. (2011) 'From planning process to self-organisation: can context control help ensure the success of IT projects in public administration?', EGOV 2011, August/September 2011 in Delft, The Netherlands. Electronic Government and Electronic Participation: Joint Proceedings of Ongoing Research and Projects of IFIP EGOV and ePart 2011, Trauner Verlag, Linz, Austria, pp.117-124.

Scholl, M. and Büschenfeldt, M. (2012) 'Anforderungs-Assessment in der öffentlichen Verwaltung Deutschlands', in Schweighofer, E., Kummer, F. and Hötzendorfer, W. (Eds.): Transformation juristischer Sprachen. Tagungsband des 15. Internationalen Rechtsinformatik Symposions IRIS 2012, University of Salzburg, Österreichische Computer Gesellschaft, 23-25 February 2012,Vienna.

Schwenk, J. (2010) Sicherheit und Kryptographie im Internet, Vieweg+Teubner, Wiesbaden, http://www.springerlink.de/content/u259374530106m05/ (Accessed on 5 January, 2011).

Talia, D. and Trunfio, P. (2010) 'How distributed data mining tasks can thrive as knowledge services', Communications of the ACM, Vol. 53, No. 7, pp.132-137.

von Hippel, E. (2005) 'Anwender-innovationsnetzwerke': hersteller entbehrlich', in Lutterbeck, B., Gehring, R.A. and Bärwolff, M. (Eds.): Open Source Jahrbuch, Lehmanns Media, Berlin, pp.450-461.

von Lucke, J. (2010) Open Government: Öffnung von Staat und Gesellschaft, Gutachten für die Deutsche Telekom AG zur T-City Friedrichshafen, Zeppelin University, https://www.zu.de/ info-de/institute/togi/assets/pdf/JvL-100509-Open_Government-V2.pdf (Accessed on 6 May, 2014) 
von Lucke, J. and Geiger, C. (2010) Open Government Data: Frei verfügbare Daten des öffentlichen Sektors, Gutachten für die Deutsche Telekom AG zur T-City Friedrichshafen, Zeppelin University, https://www.zu.de/info-de/institute/togi/assets/pdf/TICC-101203-Open GovernmentData-V1.pdf (Accessed on 6 May, 2014).

von Lucke, J. and Reinermann, H. (2014) Speyerer Definition von Electronic Government. foev.dhv-speyer.de/ruvii/Sp-EGov.pdf (Accessed on 27 February, 2014).

Weber, M. (1968) Gesammelte Aufsätze zur Wissenschaftslehre, Tübingen.

Willke, H. (1998) Systemtheorie III.: Grundzüge einer Theorie der Steuerung komplexer Sozialsysteme, Lucius \& Lucius, Stuttgart.

Willke, H. (2001) Systemisches Wissensmanagement, 2nd ed., Lucius \& Lucius, Stuttgart.

Willke, H. (2007) Smart Governance: Governing the Global Knowledge Society, The University of Chicago Press, Chicago, IL, p.222.

Zeppenfeld, K. and Finger, P. (2009) 'Service-orientierte architektur mit webservice', SOA und WebServices (Informatik im Fokus), Springer Berlin - Heidelberg. Berlin, pp.69-86.

\section{Notes}

${ }^{1}$ The term is not new - it became a subject of discussion as early as 1966 when the sociologist Robert E. Lane spoke of 'knowledge societies'.

${ }^{2}$ http://ivmhoch2.de/resources/BS_Sonderdruck+04_13_Artikel+Seite+19.pdf (Accessed on 5 May, 2014).

${ }^{3}$ Jürgen Habermas sees the consideration (inclusion) of all interested parties, issues, and opinions as a vital condition for 'authority-free' discourse in deliberative processes (Habermas, 1994).

${ }^{4}$ As per Tim Berners-Lee's statement in 'Standards and the Future of the Internet, Geneva, 2008, (Accessed on 10 January, 2011), http://www.openforumeurope.org/library/geneva/ declaration/manifesto-with-logos-final.pdf

${ }^{5} \mathrm{http}$ ://e-konsultation.de/opengov/ablauf (Accessed on 12 September, 2012). 